\title{
Single Nucleotide Polymorphism (SNP) 316 on Calpain Gene in Aceh Cattle
}

\author{
Teuku S. Rosa ${ }^{1,8}$, Al Azhar ${ }^{2,8^{*}}$, Muslim Akmal ${ }^{3,8}$, Muhammad Hambal ${ }^{4}$, Triva M. Lubis ${ }^{5}$, Teuku R. Ferasyi ${ }^{6}$, Sukmawan \\ F. Santosa ${ }^{7}$ \\ ${ }^{1}$ Master Program of Veterinary Public Health, Faculty of Veterinary Medicine, Universitas Syiah Kuala, Banda Aceh 23111 \\ Indonesia \\ ${ }^{2}$ Laboratory of Biochemistry, Faculty of Veterinary Medicine, Universitas Syiah Kuala, Banda Aceh 23111 Indonesia \\ ${ }^{3}$ Laboratory of Histology, Faculty of Veterinary Medicine, Universitas Syiah Kuala, Banda Aceh 23111 Indonesia \\ ${ }^{4}$ Laboratory of Parasitology, Faculty of Veterinary Medicine, Universitas Syiah Kuala, Banda Aceh 23111 Indonesia \\ ${ }^{5}$ Laboratory of Physiology, Faculty of Veterinary Medicine, Universitas Syiah Kuala, Banda Aceh 23111 Indonesia \\ ${ }^{6}$ Laboratory of Veterinary Public Health, Faculty of Veterinary Medicine, Universitas Syiah Kuala, Banda Aceh 23111 Indonesia \\ ${ }^{7}$ Laboratory of Research, Faculty of Veterinary Medicine, Universitas Syiah Kuala, Banda Aceh 23111 Indonesia \\ ${ }^{8}$ Center for Collaborative Research Animal Biotechnology and Coral Reef Fisheries (CCR ANBIOCORE), USAID-SHERA.
}

\begin{abstract}
Genetic polymorphisms of $\mu$-calpain, a calcium-dependent protease specifically expressed in muscle and related to meat tenderness, have been investigated in cattle worldwide, but not well documented in Indonesian beef cattle. This study was done to evaluate the frequency of SNP 316 in the $\mu$-calpain gene in Aceh cattle, a local Indonesian beef cattle plays important role in the fulfillment of red meat for peoples in Aceh and its neighboring areas. For this purpose, genomic DNA was isolated from 29 sirloin meats samples collected from cull, female aceh cattle slaughtered at the Slaughter House of Banda Aceh. The cattle were purposively selected based on physical characteristics and hair colors referred to Indonesian law. For the SNP genotyping, PCR-RFLP methods were set up. The results showed all three genotypes namely CC, CG, and GG were found in Aceh cattle. The allele and genotype frequencies of SNP CAPN316 in the CAPN gene were: $\mathrm{C}-0.14$ and $\mathrm{G}-0.86$; $\mathrm{CC}-3.4 \%, \mathrm{CG}-20.7 \%$ and $\mathrm{GG}-75.9 \%$. The observed and expected frequencies of CAPN SNP 316 in the cattle population examined were GG 22.0 and 21.6, CG 6.0 and 6.9, and $\mathrm{CC} 1.0$ and 0.6 .
\end{abstract}

Keywords: Aceh cattle, calpain, allele, genotype.

\section{Introduction}

Aceh cattle is Indonesian local beef cattle originated from the crossing of Bos Indicus, Bos Javanicus and Bos Sondaicus [1]. The cattle have good genetic potential as shown by average body weight $253 \pm 65$ (male) and $148 \pm 37 \mathrm{~kg}$ (female), carcass percentage ranges from 49$51 \%$ [2], and total meat fat 6\% [3], and marbling score is 1 [4]. Aceh cattle are superior to exotic cattle because they are adaptive to the warm, humid tropical climates [5][6], and have better resistance to infectious and parasitic diseases [2].

The significant role of Aceh cattle for the fulfillment of red meat in Aceh province and its neighboring provinces has been documented [2]. The role is now challenged by a significant decreased in population numbers, smaller body size and declined genetic quality due to inbreeding and slaughtering of productive females to fulfill market demand [7].

Efforts to improve genetic quality of Aceh cattle has been done by identifying phenotypic diversity of the cattle [2], determining its genetic relationship based on displacement-loop region of microsatellite DNA [1], and by establishing Indonesian National Standard criteria for
Aceh cattle seedstocks (SNI 7651.3.2013) and by grading heifer seedstocks at the breeding center BPTU-HPT of Indrapuri [8]. Whilst results of polymerase chain reactionrestriction fragment length polymorphism (PCR-RFLP) based molecular study showed novel mutation found in myostatin gene of Aceh cattle [9], no studies were done to explore diversity in the genes related to meat quality of the cattle. Among gene where nucleotide variations might influence meat tenderness, protein content and quality is calpain [10]. Calpain is a protease enzyme functions to degrade myofibril cell proteins and specifically expressed in muscles [11]. This study was done to identify single nucleotide polymorphism at the position of 316 of the $\mu$ calpain gene (CAPN SNP 316) in Aceh cattle have different hair colors.

\section{Materials and Methods}

\subsection{Ethical clearance}

All protocols used in this study have been approved by the Veterinary Ethics Committee of Faculty of Veterinary Medicine of Universitas Syiah Kuala Number 28/KEPH/1I/2018. 


\subsection{Sample collection}

Fresh sirloin meats (250 gram each) of 29 Aceh cattle have different hair colors (red-brown/ brick, red, grayishblack, straight yellow and white) were purposively purchased in triplicate from the Slaughter-House of Banda Aceh. Meat samples were kept $\operatorname{cool}\left(4^{\circ} \mathrm{C}\right)$, brought to the Laboratory of Research, Faculty of Veterinary Medicine of Universitas Syiah Kuala, and stored at $-20^{\circ} \mathrm{C}$ before the examination.

\subsection{DNA Isolation}

Genomic DNA Genomic DNA was extracted from fresh meats using PureLink ${ }^{\mathrm{TM}}$ Genomic DNA Mini Kits and protocol. DNA extracts were electrophorized on $1 \%$ agarose gel stained with SYBR $^{\mathrm{TM}}$ Safe (Invitrogen) staining solution. DNA bands were visualized and documented by using a digital gel imager (BioRad, USA) [9].

\subsection{Polymerase Chain Reaction}

The SNP 316 CAPN fragment (709 bp) is PCR amplified using forward primer $\left(5^{\prime} \rightarrow 3^{\prime}\right)$ CCAGGGCCAGATGGTGAA and reverse primer $\left(5^{\prime} \rightarrow 3^{\prime}\right)$ CGTCGGGTGTCAGGTTGC. A $25 \mu \mathrm{l}$ of PCR reaction containing $1 \mu \mathrm{l}$ of each primer (final concentration of $50 \mathrm{pmol}), 12.5 \mu \mathrm{l}$ of GoTaq Green PCR master mix (Promega Corporation, Madison, WI), and $120 \mathrm{ng}$ of DNA template was prepared and run using a BioRad thermal-cycler. The PCR conditions used were initial denaturation ( 1 cycle) at $95{ }^{\circ} \mathrm{C}$ for 5 minutes, followed by 35 cycles of three step PCR reactions consisting of denaturation at $95^{\circ}$ for 45 seconds, annealing at $65{ }^{\circ} \mathrm{C}$ for 45 seconds and extension at $72{ }^{\circ} \mathrm{C}$ for 45 seconds, and ended with final extension at $72{ }^{\circ} \mathrm{C}$ for 5 minutes.

\subsection{Restriction Fragment Length Polymorphism}

The PCR products, $16 \mathrm{ng}$ each, were digested with Btg I restriction enzyme (Invitrogen) for 4 hours at $37{ }^{\circ} \mathrm{C}$. The reaction was prepared by mixing $5 \mu \mathrm{L}$ of PCR product with $2.5 \mathrm{ml}$ of $10 \mathrm{X}$ digestion buffer, $16.5 \mu \mathrm{L}$ of nucleasefree water, and $1 \mathrm{IU}$ of Btg I enzyme (Invitrogen). The products were electrophorized in $2 \%$ agarose gel at 80 Volt for 75 minutes, stained with ethidium bromide, and viewed using digital gel imager (BioRad).

\subsection{Data Analysis}

Based on DNA marker bands, the frequency of alleles, genotypes, and heterozygosity of expectations and observations will be determined. The degree of polymorphism will be calculated using the formula

$$
P i C i=1-\sum p_{i j}^{2}[12]
$$

A chi-square test was used to determine whether the allele distribution meets the Hardy-Weinberg balance [9].

\section{Results and Discussion}

The results showed that all three calpain genotypes namely CC, CG, and GG were found in Aceh cattle. The allele and genotype frequencies of SNP 316 in CAPN gene were: $\mathrm{C}-0.14$ and $\mathrm{G}-0.86$; $\mathrm{CC}-3.0 \%, \mathrm{CG}-$ $21.0 \%$ and $\mathrm{GG}-76.0 \%$. The observed and expected frequencies of CAPN SNP 316 in the cattle population examined were GG 22.0 and 21.6, CG 6.0 and 6.9, and CC 1.0 and 0.6 .
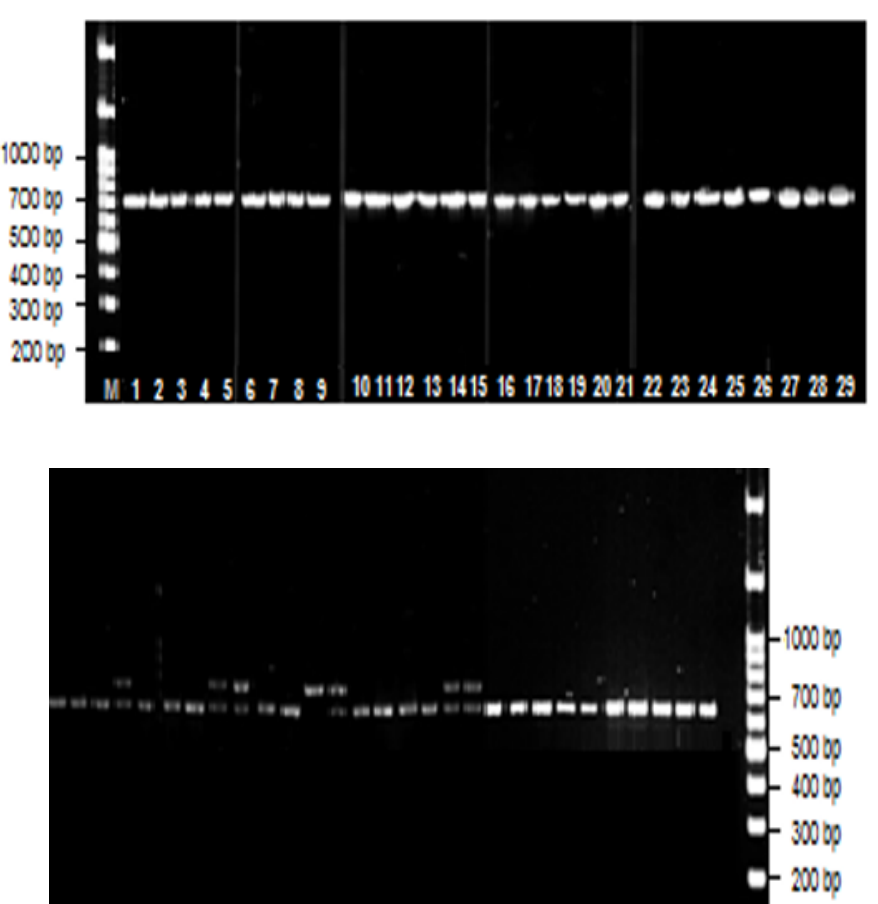

123456789101112131415161718192021223242526272820

Fig. 1. Electrogram showing results of CAPN SNP 316 gene digestion using the $\mathrm{Btg} 1$ restriction enzyme. Line 12: CC genotype, line 4, 8, 9, 13, 18, 19: CG genotype, and besides line: GG genotype $\mathrm{M}=100 \mathrm{bp}$ DNA leader.

Table 1. Allele and genotype frequencies of CAPN gene in aceh cattle

\begin{tabular}{lll}
\hline Total genotif & $\begin{array}{l}\text { Genotype } \\
\text { frequency }\end{array}$ & Allele Frequency \\
\hline $\mathrm{GG}=22 ; \mathrm{CG}$ & Freq $(\mathrm{GG})=0.76 ;$ & Frequency $(\mathrm{C})=0.14$ \\
$=6 ; \mathrm{CC}=1$ & Freq $(\mathrm{CG})=0.21 ;$ & Frequency $(\mathrm{G})=0.86$ \\
& Freq $(\mathrm{CC})=0.03$. & \\
\hline
\end{tabular}

Table 2. Allele and genotype frequencies of CAPN SNP 316 gene in aceh cattle

\begin{tabular}{lccc}
\hline \multicolumn{2}{c}{ Heterozygosity } & $\begin{array}{c}\text { Polymorphis } \\
\text { m degree }\end{array}$ & $\begin{array}{c}\text { Hardy-Weinberg } \\
\text { Equilibrium }\left(\mathbf{X}^{\mathbf{2}}\right)\end{array}$ \\
\cline { 1 - 2 } Observed & Expected & 0.49 & 0.95 \\
CC $=1$ & 0.6 & & \\
CG $=6$ & 6.9 & & \\
GG $=22$ & 21.5 & & \\
\hline
\end{tabular}

Polymorphism of CAPN is the most diversity studied about meat quality because the gene encodes the large subunit of $\mu$-calpain, an enzyme related to the meat 
tenderization process [13] and marbling [14]. The gene is located at chromosome 29 [15].

This study that is done to investigate SNP 316 of the CAPN1 gene found that the gene is polymorphic at Aceh cattle populations as shown by the occurrence of GG, GC and CC genotypes that distributed following the Hardy Weinberg equilibrium $\left(\chi^{2}=0.95\right)$. These results may reflect the actual allelic and genotypic frequencies for the corresponding CAPN locus in Aceh cattle populations. Distribution of the three genotypes in agreement with Hardy-Weinberg equilibrium was also reported in Simmental bulls [16], Brangus and Brahman bulls [17].

Whilst the results of some previous studies showed the absence of CAPN1 CC genotype in Simmental bulls [16, 18], Hereford and Limousin cattle [18], our study showed the presence of CAPN1 CC genotype in Aceh cattle. The low 0.14 frequency of $\mathrm{C}$ allele found in Aceh cattle supports reports found the low or absence of $\mathrm{C}$ allele in different cattle herds [17, 19, 20].

Previous studies showed that the SNP G316A of the CAPN1 gene studied occurs in exon 9 (alleles $\mathrm{C} / \mathrm{G}$ ), resulted in the substitution of alanine by glycine in the amino acid 316 of the protein-domain II $[17,21]$. This amino acid substitution has been showed to related to the final weight and average weight gain of Brangus cattle [21], and the meat quality of Brangus [21], Aberdeen Angus-sired beef cattle [22] and Nellore cattle [23]. CAPN1 G316A polymorphisms also influence the fattening performance of Simmental bulls [16]. Since these effect were not addressed yet in this study, the further experiment must be done to investigate effects of the occurrence of the three SS, SG and GG CAPN SNP 316 on meat and production performance of Aceh cattle by involving not only larger numbers of subjects, but also Aceh cattle bulls.

\section{Conclusion}

The occurrence of the GG, GC, and CC genotypes of CAPN SNP 316 in aceh cattle in appreciable frequencies showed the diversity of the CAPN gene that distributed following the Hardy-Weinberg equilibrium. Further study involving larger samples from both sexes needs to do in order to map the diversity in the Aceh cattle populations and to explore the effects of the polymorphisms on the production and reproduction of the cattle.

\section{Acknowledgment}

This paper is supported by USAID Sustainable Higher Education Research Alliance (SHERA) Program - Center for Collaborative Research Animal Biotechnology and Coral Reef Fisheries (CCR ANBIOCORE) as well as the Slaughter-House of Banda Aceh, Indonesia. High appreciation was also directed to the Head and Staff of the Slaughter-House of Banda Aceh for their help in sample collection.

\section{References}

1 Abdullah MAN: Relationship of Aceh cattle using displacement-loop region. Agripet. 2008; 8: 9-14.

2 Abdullah MAN, Noor RR, Martojo $\mathrm{H}$, et al.: Keragaman fenotipik sapi aceh di Nanggroe Aceh Darussalam [Phenotypic variability of aceh cattle in Nanggroe Aceh Darussalam]. Journal of the Indonesian Tropical Animal Agriculture. 2007; 32: 11-21.

3 Manan, D: Peningkatan Potensi SDGH Sapi Aceh. Balai Pembibitan Ternak Unggul (BPTU ) Sapi Aceh Indrapuri, Aceh Besar. 2011.

4 Azhar A, Lubis TM, Razali: Nutrient composition and diversity of genes influence tenderness and cooking smells of the meat of local aceh cattle. Universitas Syiah Kuala, Banda Aceh. 2016; p. 74.

5 Noor RR: Genetika Ternak. Penebar Swadaya, Jakarta. 2004.

6 Mukhtar, Jamaliah, Saumar H.: Diversity of phenotypes of female Aceh cattle in Indrapuri BPTU-HPT. Jurnal Ilmiah Peternakan. 2015; 3: 3438.

7 Armansyah T, Azhar A, Siregar TN: Isozymes analysis to investigate genetic variation as an effort to developpure breed of aceh's cattles. Jurnal Veteriner. 2011; 12: 254-262.

8 Putra WPB, Sumadi, Hartatik T, et al.: Identification of grade in female aceh cattle breeds at the indrapuri breeding center. Jurnal Peternakan. 2018; $15,9-14$.

9 Azhar A, Akmal M, Hambal M, et al.: Polymorphism of mysotatin gene in the local aceh cattle. In The $2^{\text {nd }}$ International Conference on Tropical Animal Science and Production (Tasp) 2019 and The $2^{\text {nd }}$ International Conference on Native Chicken (ICONC) 2019. Suranaree Univesity of Bioctechnology, Nakhon Ratchasima, Thailand. 2019; pp. 120-125.

10 Bhat ZF, Morton JD, Mason SL, et al.: Role of calpain system in meat tenderness: A review. Food Science and Human Wellness. 2018; 7: 196-204.

11 Lian T, Wang L, Liu Y: A new insight into the role of calpains in post-mortem meat tenderization in domestic animals: a review. Asian-Australas. J. Anim. Sci. 2013; 26: 443-454.

12 Budak H, Pedraza F, Cregan PB, et al.: Development and utilization of SSRs to estimate the degree of genetic relationships in a collection of pearl millet germplasm. Crop Science. 2003; 43: 2284-2290.

13 Corva P, Soria L, Schor A, et al.: Association of CAPN1 and CAST gene polymorphisms with meat tenderness in Bos taurus beef cattle from Argentina. Genet. Mol. Biol. 2007; 30: 1064-1069.

14 Cheong HS, Yoon DH, Park BL, et al.: A single nucleotide polymorphism in CAPN1 associated 
with marbling score in Korean cattle. BMC Genet. 2008; 9: 33-39.

15 Page BT, Casas E, Quaas RL, et al.: Association of markers in the bovine CAPN1 gene with meat tenderness in large crossbred populations that sample influential industry sires. J. Anim. Sci. 2004; 82: 3474-3481.

16 Ardicli S, Dincel D, Samli H, et al.: Effects of polymorphisms at LEP, CAST, CAPN1, GHR, FABP4 and DGAT1 genes on fattening performance and Carcass traits in Simmental bulls. Arch. Anim. Breed. 2017; 60: 61-70.

17 Soria LA, Corva PM, Huguet MJ, et al.: Bovine $\mu$ calpain (CAPN1) gene polymorphisms in brangus and brahman bulls. BAG - Journal of Basic and Applied Genetics. 2010; 21: 61-69.

18 Li X, Ekerljung M, Lundstrom K, et al.: Association of polymorphisms at DGAT1, leptin, SCD1, CAPN1 and CAST genes with color, marbling and water holding capacity in meat from beef cattle populations in Sweden. Meat Sci. 2013; 94: 153-158.
19 Allais S, Journaux L, Leveziel H, et al.: Effects of polymorphisms in the calpastatin and mu-calpain genes on meat tenderness in 3 French beef breeds. J. Anim. Sci. 2011; 89: 1-11.

20 Curi R, Chardulo L, Mason M, et al.: Effect of single nucleotide polymorphisms of CAPN1 and CAST genes on meat traits in Nellore beef cattle (Bos indicus) and in their crosses with Bos taurus. Anim. Genet. 2009; 40: 456-462.

21 Miquel MC, Villarreal E, Mezzadra C, et al:: The association of CAPN1 316 marker genotypes with growth and meat quality traits of steers finished on pasture. Genet. Mol. Biol. 2009; 32: 491-496.

22 Gill JL, Bishop SC, McCorquodale C, et al.: Association of selected SNP with carcass and taste panel assessed meat quality traits in a commercial population of Aberdeen Angus-sired beef cattle. Genet. Sel. Evol. 2009; 41: 36-47.

23 Pinto LF, Ferraz JB, Meirelles FV, et al.: Association of SNPs on CAPN1 and CAST genes with tenderness in Nellore cattle. Genet. Mol. Res. 2010; 9: 1431-1442. 